\title{
Community resilience demonstrated through a Te Ao Māori (Ngāti Manawa) lens: The Rāhui
}

Leila-Dawn Ngaroimata Kauri Rewi (Ngāti Manawa, Ngā Puhi, Whānau-ā-Apanui) and Jeanette Louise Hastie (Ngāti Ranginui), Toi Ohomai Institute of Technology, Aotearoa New Zealand

\begin{abstract}
INTRODUCTION: This research project is associated with a small rural community utilising the Te Ao Māori (Ngāti Manawa) understanding of Rāhui, as a means of decreasing the possibility of negative impacts for their mostly Māori population, during the Covid-19 pandemic that was experienced in March 2020 in Aotearoa New Zealand. Rāhui is a conservation measure shrouded in tapu designed to limit, restrict or prevent access to the natural environment. For example, Te Wao Tapu nui a Tāne protecting in the process the mauri of our rivers, lakes, streams following a mishap or misfortune such as a drowning. Equally as important, Rāhui was used as a proactive means of conservation.

METHOD: Using mixed methods, this study highlights both positive and challenging experiences in the statistical and thematic analysis that may inform future public health planning for the inevitable and ongoing effects of pandemic responses in Aotearoa New Zealand which are potentially transportable beyond Aotearoa New Zealand.

IMPLICATIONS: This research identified how Ngāti Manawa of Murupara, utilised Rāhui as a mechanism of resilience in order to keep local residents thriving and healthy during and after the Covid-19 pandemic lockdown by setting up checkpoints on the borders of their rohe, and restricting the vehicle and human traffic into Murupara. Support for the Rāhui was significant from five hapū leaders and from the community survey illuminating a sense of safety that the checkpoints offered to a vulnerable and mostly Māori rural community.
\end{abstract}

Keywords: Murupara Ngāti Manawa; pandemic response; tikanga; rāhui; checkpoints; Covid-19

Health outcomes for Māori during three, historical, nationwide pandemics that include the Spanish Flu in 1918, the Influenza A (H2N2) pandemic in 1957, and the Influenza A (H1N1) pandemic in 2009 bring to light ethnic inequalities associated with significant loss for Māori in terms of longterm declining health, and high mortality rates (Summers et al., 2018). The public health response displayed several strategies and frameworks that were developed to monitor, coordinate and respond to pandemics. This research will focus on the relevance of Rāhui as a process that can protect Māori through a tikanga (cultural) understanding of protection or restrictions during the 2020 Covid-19 pandemic in New Zealand. The purpose of Rāhui for the Māori population is to protect all things living and all things unseen (Mead, 2003). Rāhui can be adopted and adapted to any given situation such as, but not limited to, a nationwide
AOTEAROA

NEW ZEALAND SOCIAL WORK 33(4), 65-76.

CORRESPONDENCE TO: Jeanette Louise Hastie jan.hastie@toiohomai.ac.nz 
pandemic event. Rāhui is recognised in legislation in fisheries and environmental protection. However, Rāhui after death by drowning is associated with avoiding personal, physical or spiritual contamination resulting from eating seafood from an area made tapu by the death and is associated with restricting access to these areas. This understanding has no legislative backing but is often adhered to by the general public (McCormack, 2011).

McCormack (2011) describes the relevance of Rāhui for Māori as protection of all elements pertaining to health such as, but not limited to, mental, spiritual, physical or emotional health. Furthermore, it is not just for land and water restrictions, but is also to help contain and aid in the elimination of elements of sickness, disease and infection. There is a lack of understanding from many legislators over the interpretation of Rāhui or an unwillingness to acknowledge and create a legal form of Rāhui that accurately depicts the practices and origins of Rāhui. Consequently, Maxwell and Penetito's (2007) view of Rāhui illustrates that traditional practices of Rāhui are adapting to modern times, resulting in the different ways of enforcing and the lifting of Rāhui.

Whaanga and Wehi (2017) advocate that legislation should now examine Rāhui from a different point of view and not simply as a temporary conservational restriction, but as Kaitiakitanga (guardianship), and Rangatiratanga (autonomy) that forms protection over people. During the 2020 Covid-19, level-four lockdown period, the small community of Murupara enacted traditional Rāhui where they restricted the flow of access of people and products to and from the community with a checkpoint system that provided data for tracking and tracing the movements of people in and around the area.

Murupara is located in the Bay of Plenty with a population of 1,815 residents and is surrounded by two major rivers, the mighty
Rangitaiki river and the Whirinaki river. A total of $46 \%$ of the residents are one-parent families and the median income is $\$ 17,100$ per annum. Some $10 \%$ of the population is aged 65 years and over with $31 \%$ aged under 15 years (Statistics NZ, 2018).

A community checkpoint was utilised on the borders of Murupara as a way to provide information and advice to people travelling throughout the area but did not have any legal standing in making people leave the area.

\section{Methodology}

Murupara is named after Murupara a taniwha [a very large eel] our Kaitiaki who inhabited the Rangitaiki river from Kiorenui to an area below the old bridge, where her ana (cave) is. Therefore, it follows that we seek to emulate Murupara our taniwha as Kaitiaki for all in our rohe [Carers / Protectors / Preservers]. Kaitiaki is our status thus our obligation to act accordingly. We are also Te Mana Motuhake the inherited permanent unique authority that we discharged in our respective tribal rohe over every aspect of our lives, our physical intellectual, and spiritual wellbeing. Karakia, a powerful tool exercised to ensure the preservation of our individual tapu and mana. (HL4, 2020)

This research affirms Te Ao Māori (Ngāti Manawa) as privileged knowledge and therefore legitimate authority associated with the Rāhui that was placed on Murupara and the surrounding districts during the 2020 level 4 lockdown as a response to the Covid-19 virus that overwhelmed the world.

(Research approval granted by the Toi Ohomai Research Committee 12/11/20: Reference number 200071).

\section{Aim of the research}

The purpose of this mixed-method research was to highlight how the understanding of 
Rāhui supported the Murupara community: 1. To feel safe during the uncertainty of the level 4 lockdown period due to the Covid-19 pandemic; 2. Whether the understanding of Rāhui supported the community's understanding of the need to adhere to the conditions of staying at home and social distancing; and 3. If another Rāhui would be supported if another pandemic visits the shore of our country.

\section{Method}

This research project collected information from two sectors of the community that included interviewing five Ngāti Manawa Iwi hapū leaders face to face and conducting an online survey in the community of Murupara through the local community Facebook page.

\section{The hapū leaders of the Ngāti Manawa Iwi}

Five hapū leaders were interviewed about their perspective of the Rāhui in the local community through face-to-face, semistructured interviews with a general set of questions. These perspectives included learnings that came from the Rāhui and what the community will take going forward to the next pandemic. Questions for the hapū leaders included capturing their understanding of Rāhui through a Te Ao Māori (Ngāti Manawa) perspective and how this supported their understanding of the level 4 lockdown in Aotearoa New Zealand. Other questions included whether Rāhui supported their sense of safety for themselves and their whānau and if they could identify both positive and negative aspects of the Rāhui.

\section{Online survey}

An online community survey asked residents of Murupara how informed they felt about the pandemic Covid-19 response and the resultant level 4 lockdown. Furthermore, they were asked if they understood the meaning of the Rāhui placed in Murupara and if they were supportive of this happening again in the future as a response to another pandemic.

\section{Analysis}

The individual interviews with hapu leaders were transcribed word for word and both researchers thematically analysed the kōrero (discussion). A summary of themes from individual interviews was provided to the hapū leaders and their permission was gained to have them released for analysis. Themes within the data identified how members of the community evaluated their safety both from a personal and community understanding when threatened by the Covid-19 virus.

Analysis of the transcript data was guided by the process of latent thematic analysis through interpretation. Latent thematic analysis takes the position of identification or examination of the underlying assumptions and patterns that are associated with the semantic content of the data (Braun \& Clarke, 2006). This included common language or concepts that were decoded within and across the interview data. The collated themes and a draft of the report were circulated to the individual interviewees for their discussion and approval prior to submitting the report.

The data from the community survey was assessed from both numerical and percentage perspectives and the personal comments were themed by latent thematic analysis. The results for the community survey are discussed after the interpreted one-on-one interviews for this article.

\section{Results}

One-on-one hapū leader interviews.

Five hapū leaders were interviewed and were assigned a moniker such as $\mathrm{H} 1$ or $\mathrm{H} 2$ etc., to identify their responses.

Six themes were identified throughout the transcripts of the one-on-one 
interviews and included understanding; karakia; whakawhanaungatanga; safety; support; communication and community relationships.

\section{Themes}

\section{Understanding}

The Rāhui helped me have a better understanding of what lockdown means, it helped many whānau understand the severity of the Covid-19 disease and the nationwide response. (HL1, 2020)

There were several preliminary lessons to understand the effectiveness of the New Zealand government pandemic response, which was the four-level alert system that was introduced during the Covid-19 worldwide pandemic (Cave \& Solomon, 2020). Having an informed public was imperative to the effectiveness of the New Zealand government's response plan. The response was proactive, evidenced-based and communication was highly effective ensuring the public had a logical and clear understanding of the Covid-19 pandemic (Wilson, 2020). The country's response to the Covid-19 pandemic resulted in low levels of population disease, and to some degree the elimination of Covid-19 (Ministry of Health $[\mathrm{MoH}], 2020)$. The Māori response in rural communities that placed Rāhui on their borders would have some accountability to the country's overall result, specifically to their community by having low to no confirmed cases in their community. It helped community members understand the characteristics of Covid-19, by understanding transmission sources, and how to take action to protect themselves and their whānau. Through the rural community responses, the Ministry of Health understood that there needed to be an updated Covid-19 response plan that was specific to Māori health and wellbeing that collaborated with Māori leadership to achieve Māori health equity (MoH, 2020).

Māori iwi and hapū leaders around the country interpreted and understood the government response as placing a Rāhui on the country. In this instance, emerging problems were identified faster by local community members than council members (HL4, 2020). This was due to the fact community members were local and on hand to monitor the needs of the community. Additionally, many community members also perceived the nationwide situation of level 4 lockdown as a practice of Rāhui.

The New Zealand government placed a four-level lockdown right across our country and this was understood from a Te Ao Māori perspective and interpreted as a Rāhui (HL5, 2020). Rāhui helped Māori understand the severity of the lockdown and Covid-19, by linking the inequitable mortality and morbidity of Māori in past influenza pandemics, and how it is evident that these inequities continue today for most community outbreak diseases (Dong, Du \& Gardener, 2020). The Rāhui was a Te Ao Māori response to prevent Covid-19 disparities and minimise transit and prevent a community outbreak in a Māori community. This captured and established a better understanding for what the New Zealand government sought to achieve with the lockdown (HL2, 2020).

The practice of Rāhui during the lockdown and Māori being able to relate the response with traditional Māori practices such as the Rāhui is an educational tool for the younger generation. Through the government officials not preventing Māori erecting their checkpoints and by working in partnership with Māori has helped in the efforts to protect Māori tikanga from the ongoing threat of Covid-19 on the Māori culture (Parahi, 2020). Many in the new generation believed Rāhui was for drownings and for conservation measures only however, Covid-19 showed that Rāhui is not just for those purposes. The Ngāti Manawa Rāhui proved that Rāhui can be used to protect living people alongside the purpose of preservation and restoration. These are the teachings and cultural knowledge that the future generation need to acquire (HL4, 2020). 


\section{Karakia}

The karakia is important when placing the Rāhui, karakia needs to be done. Karakia enables the protection method. We performed the karakia even though we were vulnerable, it was our job and we done it. (HL4, 2020)

Karakia, in its true essence, is providing protection and offering spiritual guidance and in its most visible form can be used for the many cultural events Māori are involved in such as tangihanga, meetings and unveilings. Moreover, karakia are also used for life aspects such as safe traveling to and from unknown or known locations, for illness or disease, and sunrise or sunset (Otago University, 2020). The survival of Māori and their culture relies heavily on tupuna and their teachings of tikanga, te reo, kawa, and karakia. Te Ao Māori and the world of karakia have evolved throughout the Covid-19 pandemic. Many New Zealanders across the country took comfort in online karakia, as this was focused on offering a sense of protection and safety associated with the power produced through karakia (Hurihanganui, 2020). Karakia was provided at many borders, for example the most recent lockdown in the AucklandWaikato region where volunteers of Māori descent provided morning and evening karakia with the focus of protection and safety for travellers (Earley, 2020). Karakia is often utilised in myriad situations and has been redefined as adaptable and flexible during lockdown and according to one hapū leader, it needs to be practised more so future generations can pass their knowledge of karakia on to the next generation (HL2, 2020).

Karakia and Rāhui work in a partnership. When a person performs a karakia, even for themselves, for example when someone travels, sleeps, or when performing an action of any sort, you karakia and in some way you are placing a Rāhui on yourself, therefore restricting and preventing any harm toward yourself (HL1, 2020). Karakia is an essential part of Rāhui. Without the correct karakia and without the correct rituals for Rāhui, the karakia and Rāhui will be perceived as not providing full protection. Karakia for Rāhui is usually performed by an elder of rank, in most situations, a Tohunga (cultural leader). During Covid-19, kaumātua and kuia (hapū leaders/elders) in Murupara were a population that was the most vulnerable, however, they upheld their duty and performed the Rāhui ritual and karakia as it was their job, "and they done it" (HL4, 2020). Rāhui that were placed in rural and remote areas preferred checkpoints to continue during level two and level three; however, due to most volunteers being able to return to work, checkpoint volunteer numbers declined therefore checkpoints were no longer resourced to continue (Johnsen, 2020b). Karakia was again performed to lift the Rāhui just as karakia was performed to place the Rāhui showing the importance karakia is to the effectiveness of Rāhui (HL4, 2020).

Mana whenua (indigenous people) placing Rāhui on the Ngāti Manawa area allowed hapu members ownership of the Rāhui, ownership of the checkpoints and a responsibility to protect the vulnerable members of Murupara and surrounding communities including kaumātua, kuia and tamariki of the Ngāti Manawa iwi (HL3, 2020). Giving Māori ownership, responsibility and authority enables Māori to be accountable for their actions. There were many Māori living across the country that were not as resilient as others, for Murupara allowing the Rāhui to proceed was a gesture of giving hapū leaders and community members mana whenua a sharing of the responsibility of protecting the iwi and community (HL4, 2020). Karakia strengthens the ties between Māori and tikanga as these are all aspects of mana whenua, authority, responsibility and accountability, by Māori, for Māori (Waititi, 2020).

\section{Whakawhanaungatanga}

There was a lot of aroha with whānau, community members, hapū and iwi members throughout the Rāhui in several ways. There was ample respect 
and caring for one another was evident during the Rāhui. It brought a whole lot of people together this is including, other hapū and iwi. (HL3, 2020)

Whānau health and wellbeing in Te Ao Māori comes in many shapes and forms to ensure Māori are grounded and connected. The observation of whakawhanaungatanga for community members and from community members for each other was highlighted in these extraordinary times. The need to adapt to change for Māori was a challenge during the Covid-19 pandemic and was associated with the tikanga and kawa of tangihanga, greetings and gatherings. This particularly linked to social distancing rules and a restriction around numbers of people who could gather in one place at the same time. However, Māori adapted to the change quickly (Parahi, 2020).

Cultural adaption occurred in many ways for Māori, where Māori needed to change their tikanga for caring, sharing and showing aroha. Iwi across the country developed pandemic plans that adapted to the nationwide response plan and whakawhanaungatanga took the form of cooking food for vulnerable whānau, delivering essential items to the elderly which, in turn, created and built relationships (Scanlon, 2020).

The Ngāti Manawa Rāhui enabled many relationships to develop and helped the Rāhui to progress well, because without positive relationships and a common goal it would have been more difficult to support the community to be safe. There were people in the Murupara area that did not know any other residents who worked on the checkpoints and from there built a relationship with others. These people are now lifelong friends (HL2, 2020).

There were multiple facets of people working on the checkpoints. Many were small business owners, social workers, forestry workers, labourers, teachers, hospitality workers, retail and emergency service employees. These are the people that decided to adapt to the new rules and regulations of the nation, these are the people that utilised whanaungatanga to keep Murupara safe and Covid-19 free (HL3,2020).

There were local gang members working on the checkpoints in Murupara and some were from rival gangs that put their gang-related issues aside to unite against the threat of Covid-19. It did not matter metaphorically what colour they represented, it was about caring for and protecting the residents of Murupara and the wider communities. There are relationships that are ongoing to this current day that were formed during the Rāhui and that is true whakawhanungatanga. Gang members interviewed by the on-line news service Newsroom across the country, discussed the impact of a united effort which was needed to ensure the community and community members were protected, with some commenting that they were volunteering for their family and to protect Māori communities from contamination (Peters, 2020).

The New Zealand police were also in partnership with the Ngāti Manawa Rāhui. The Rāhui team reported daily information to the local Murupara police officer and when there was trouble on the checkpoints, the volunteers were able to call the officer so he could address the issue. It could be argued that the New Zealand police were lacking in resources and were not capable of sending additional officers to rural areas to ensure protection and most rural areas were assigned only one police officer during Covid-19 level 4 lockdown (Boyle, 2020). The support from the New Zealand police was appreciated and the officer assigned to Murupara was in full support of the Rāhui and checkpoints as long as the volunteers worked to the rules and regulations that were stipulated by him and the checkpoint organisers (HL4, 2020). Although the police liaison person for Murupara was asked to be part of this research, he respectfully declined. It may be that this aspect of any future 
Rāhui can be nurtured and strengthened as a resource for this community.

\section{Safety}

There is a territorial aspect of Rāhui through karakia and chanting which dates back a few generations, it is a historical form of placing a Rāhui on yourself to keep yourself safe, another form of protection and safety. Protection from the unseen enemy, I had feelings of relief when the Rāhui was placed. (HL1, 2020)

As of May 2021, Covid-19 has killed at least 3.45 million people worldwide with numbers continuing to surge upwards (WHO, 2020). The understanding associated with the need to preserve, protect through restrictions is historically embedded in the collective memory of communities that were impacted by previous pandemics in Aotearoa (Summers et al., 2018). The Murupara community and Ngāti Manawa Iwi were extremely vulnerable to Covid-19 due to their rural location, lack of resources, limited health providers and having 10\% of the population considered elderly that, according to the World Health Organisation (2020) were most at risk of dying from Covid-19 due to existing co-morbid health issues often associated with being elderly. The purpose of the Rāhui was to restrict access in and out of Murupara by setting up checkpoints and implement a track and trace system of people and their movements in and around the area in March 2020. Furthermore, the Rāhui focused on protecting the vulnerable including kuia, kaumatua, and children from an unseen threat that still at that time was little understood, from an enemy that was not visible, that had no feeling or sound, allowing community members to feel safe and protected. Moreover, the purpose of the Rāhui, according to hapū leaders, was to safeguard the local population and to preserve, maintain and save the resources in the Ngāti Manawa area such as water, natural rongoa, and food.

\section{Support}

There was a lot of support coming from all over the motu, from the top of the North Island to the bottom. Iwi from all over Aotearoa were talking about our Rāhui and how they were in full support of it. We had the support of the New Zealand Police, we reported daily happenings to him [Police Liaison] on a daily basis. (HL5, 2020)

It is recorded that Aotearoa New Zealand rural towns have higher rates of chronic diseases, higher Māori populations, more elderly and poor access to health providers (MoH, 2020). The $\mathrm{MoH}$ were slow in providing information to health providers of the exact locations of confirmed cases, which made it harder for rural communities to plan for a community outbreak (Parahi, 2020).

Murupara is a rural township that is in the Whakatāne district council catchment. The speed at which the council moved in response to the Covid-19 pandemic was far too slow for many iwi members (HL1, 2020). Furthermore, the community were not informed on a community response plan-nor was one enforced. Additionally, this created a sense of disempowerment for community members and created ill feeling toward the district council. The tactical nature of the council response to the nationwide lockdown meant that the outcome community members sought were not achieved, therefore Ngāti Manawa iwi members and hapū leaders enforced a strategy of their own with an iwi response, and placed the Rāhui (HL4, 2020). Moreover, many in the Murupara community, iwi and hapū were in full support of the Rāhui. Support was demonstrated in various ways that included donating money (koha) to purchase resources like road cones, torches and safety equipment for checkpoint volunteers.

Appreciation for the 50 volunteers who worked a 24-hour rostered schedule on two checkpoints in the Murupara Ngāti Manawa 
area was displayed in many forms including community members thanking volunteers verbally and providing a community appreciation dinner at a local marae (HL4, 2020). There was ample support shown by small local business owners who have been, and are still, experiencing financial strain due to the economic decline during the pandemic. They supported the placing of the Rāhui through volunteering or by koha of food or money (HL3, 2020).

The public needed to come together to triumph over the Covid-19 pandemic (Duncan, 2020). Furthermore, the unity that was present (and is still present to this current day) is beyond measure, not only in the Ngāti Manawa region, but across the country. Collectively, the unifying movement from Māori and their checkpoints in small rural communities helped defend the lockdown measures that would otherwise have not been supported by many Māori as it was a sacrifice of their personal freedom, their kawa and their tikanga. However, there remain significant areas of improvement for the support of Māori response plans associated with the ongoing issues, that remain important, caused by Covid-19 on Māori communities (HL3, 2020). Māori need the ongoing support for Māori initiatives such as Rāhui and Māori need to assert a perspective of equity that needs to be applied to all facets of nationwide pandemic response planning (Johnsen, 2020a).

\section{Communication and community relationships}

There was an aspect of the Rāhui that was well utilised, keeping the communication lines open, helped ease people's worries, posting daily information was the key to keeping community members worry free. Educating travellers at the checkpoint worked. Communication between surrounding hapū and iwi encouraged positive relationships. (HL2, 2020)

Aotearoa New Zealand's experience with the Covid-19 virus in terms of mortality rates was comparatively less that other countries across the globe (WHO, 2020). Aotearoa New Zealand's government acted early and decisively through effectively communicating with the nation and it could be argued that the emergency management response plan set by the government could be adapted and adopted by other countries (Fifield, 2020). The national response plan displayed well communicated policies and demonstrated accountability for this plan through an Epidemic Response Committee that developed and introduced the four-level alert system for the pandemic (New Zealand Government, 2020).

Prime Minister Jacinda Ardern placed restrictions on the entire country and the rules and regulations of the restrictions were equivalent to the rules and regulations of the Rāhui (HL5, 2020). The importance of effective communication regarding risk is ensuring all community members understand the information that has been provided. The daily briefings from the government on their goals and their obligation to reduce the spread of Covid-19 were presented exceptionally well. Alongside public and private initiatives to assist the government's efforts to contain the virus, collaborative communication proved to be beneficial for small, rural communities (Wilson, 2020).

The Ngāti Manawa hapū leaders sought input from interested community members to put restrictions on the movements of people in the area by firstly advertising on a Murupara community page via social media. Meetings that adhered to social distancing were held at Kanirangi Park and the iwi response plan for Ngāti Manawa was developed. A Rāhui was placed on Murupara that would take the form of checkpoints on all roads into Murupara. The iwi adopted the Prime Minister's nationwide response plan and reiterated the rules and regulations for the restrictions through an iwi Rāhui (HL5, 2020).

The core principles of communication during lockdown level 4 and the Ngāti Manawa 
Rāhui were to educate travellers stopped at the checkpoints on the vulnerability of Murupara and to explain the role of the iwi response. On some occasions checkpoint volunteers needed to explain why the action of the Rāhui needed to be taken and the urgency of the action. The role of the volunteers was crucial during the Rāhui as they provided an "on the ground" role conveying information between government agencies and the community, thereby keeping the communication lines open and flowing. The Rāhui volunteers created a sense of trust with the wider community because they helped explain to travellers and non-travellers changes that were happening nationwide, sometimes on a daily basis.

A good flow of communication allowed the community to feel included and informed, supported iwi autonomy and created trust, partnerships and collaboration between surrounding iwi and communities (HL2, 2020). Working on the checkpoints was voluntary and there were essential workers who would work at their paid jobs, then volunteer on rostered checkpoints (HL3, 2020). The teams working on the checkpoints recorded and collated daily data of travellers and these data were published on the local Murupara community page.

This created some tensions and mixed emotions of anger and empathy when community members realised that there were travellers coming from different regions of New Zealand to utilise Murupara resources including those items that were becoming scarce in other towns. It can be argued that panic buying caused valued resources to become scarce. The community survey demonstrated this through comments about needing more support from the government and support for other people in Murupara who were not Ngāti Manawa.

\section{Online community survey}

A total of 71 people responded to the community survey that was conducted through Manawa FM in November 2020; 63 were current residents. Four non-residents responded as well and four people who were staying in the area over the time the Rāhui was set. Non-residents have not been included in the data.

For the purpose of this report, the community survey was to assess the feeling of safety and preparedness of the community members to comply with the understanding of Rāhui. Only three (4.8\%) of the residents surveyed did not feel well informed about the community Rāhui and identified it did not support their feeling of safety during the pandemic. This denotes that sixty $(95.2 \%)$ felt well informed about the Rāhui and this knowledge increased their sense of safety. A total of $62(98.4 \%)$ of the residents indicated that they understood what the Rāhui meant with only one $(1.6 \%)$ indicating they had no understanding of Rāhui. Sixty-one (96.8\%) of the residents indicated that they would support Rāhui in the future as a response to another pandemic, leaving two (3.2\%) indicating they would not support any future Rāhui in Murupara. This suggests that one $(1.6 \%)$ of those surveyed understood Rāhui but did not support its implementation.

Written responses from the community survey highlighted common themes indicated in the hapū leaders kōrero linked to the Rāhui supporting a sense of safety:

I support the Rāhui whole heartedly. It needs to be in legislation.

When you see rival gangs for instance come together not as a gang but as a group to help keep us all safe speaks volumes on its own.

Thank you all to the Whānau who put themselves on the front line to serve and protect our people.

Diverse members of the community including those from rival local gang members engaged in serving the community emphasising them as a significant and locally available resource in 
a time of need. People came together and worked together. Friendships and respect were built and stereotypes were challenged culminating in the reduction of possible harm to a vulnerable community. This was important in terms of the suggestion from the survey that linked Mana Motuhake for the community of Murupara and need for local solutions to adversity. It could be argued that this is associated with a strengths-based understanding of community resilience and capacity for Māori organisations, and their ability to organise a response to the pandemic (McMeeking \& Savage, 2020). Moreover, the Māori mobilisation, self-responsibility and the practice of localised self-determination has been described as pivotal in the positive outcome for Māori health during the pandemic.

Some challenges were identified in the comments in the community survey. One comment in the survey asked that local gang members who could be identified by wearing their gang regalia on the checkpoints, refrain from doing so. Counterarguments were presented in the survey that discussed the local gang members as simply being a group and that they need to be reframed as members of a community and in service of that community.

The comments from the survey discussed the gratitude of a community for the volunteers who provided a sense of safety for many. A strong sense of understanding of what Rāhui means was evident in the survey underpinning the discussion of protection and prevention being the key aspects of maintaining the checkpoints in and out of Murupara and supporting a sense of safety. The survey responses were strongly in favour of supporting Rāhui in any future pandemic or the need to protect this rural community and compare with the discussion from hapū leaders in supporting the local population who were at most risk in this pandemic by championing more autonomy and authority for Māori in regard to self- determination - and striving to understand the relevance of Māori knowledge in terms of Rāhui. It is argued by the researchers that one of the key outcomes for this pandemic has been the coming together of a community, and this was described as "people coming out of the woodwork" developing connections, friendships and building a sense of community (HL3, 2020). This aspect of the Covid-19 response in Murupara creates an immeasurable nuance of a willingness to come together in a time of need, and in a collective understanding that links intrinsically to a Te Ao Māori understanding that cements this idea of preservation, protection from a deep understanding of knowing of what to do.

\section{Strengths and issues of this research}

This research has been conducted by a social work student who has lived in Murupara all of her life. She is an active and up-andcoming leader of her community. This relationship facilitated the engagement of the hapū leaders in open and honest kōrero that would not have happened had the researcher been an outsider. She also had insider knowledge of the Rāhui (Ngati Manawa). Another strength was the indepth interviews with five hapū leaders who were able to provide insight of their rohe and their collective responsibility of $\mathrm{Te}$ Mana Motuhake as an inherited authority. Their willingness to share their kōrero has ensured the legitimacy and relevance of the information.

The community survey had 63 respondents who identified themselves as residents of Murupara out of a population of approximately 1,815 (Stats NZ, 2018). Although this is a small number of respondents, it has to be remembered that Murupara has a young population, with almost one third of residents below the age of 15. Furthermore, approximately half of the residential households do not have internet access, which may have restricted access to the survey. 
Nevertheless, the findings do provide a snapshot of the feeling of the community of Murupara. While findings cannot be generalised widely across communities in Aotearoa New Zealand, the thoughts and feelings of Murupara residents are likely similar to those of people living in similar small, rural communities with a high percentage of the population being Māori.

\section{Conclusion}

The authors of this project would argue that the themes of understanding, karakia and whakawhanungatanga are closely linked to a Te Ao Māori world view.

Understanding relates to knowledge about Rāhui and its uses both in historical and contemporary times and reaches back into the collective memory of Ngāti Manawa to access a way of knowing how Rāhui can support the iwi to remain safe. Karakia relates to the process of placing a Rāhui and consolidates the spiritual nuance that accompanies Rāhui. Whakawhanungatanga is associated with the sense of community and aroha that metaphorically added another layer of keeping whānau both physically and spiritually safe during the Covid-19 pandemic.

Decisive action was the key to preventing possible aversive impacts of the deadly Covid-19 pandemic for New Zealand that could be attributed to the swift intervention from the governing Labour Party and its leader. However, it was the decisive action and support of many people coming together in this small, rural town that complemented this action by utilising their own resources and embedded community historical knowledge. This research highlights strong support for the Rāhui placed in Murupara by those interviewed one on one, and those who engaged in the online survey.

Rāhui as a key component of any pandemic response plan and is fundamental in terms of compliance for Māori through this deep understanding of the need to prevent and protect communities from an unseen enemy. Furthermore, Rāhui highlights the ability and flexibility of Māori to mobilise quickly and efficiently in a short period of time. This crucial aspect of setting up checkpoints supported a grateful community to feel safe and secure. The checkpoints provided effective communication about the community to travellers, and an added layer of safety through a track and trace system of who visited the area. Relationships were built where none had existed, and residents of Murupara were supported with information, food and friendship through a sense of service to each other in this small community. This included members of the community who live on the fringes of what is considered the social normative. Various groups came together, and each person was valued equally as a defender of those vulnerable to the complications of Covid-19 within the district.

Additionally, the Rāhui in Murupara demonstrates a sense of bravery associated with those community members who put their own health at risk to place the Rāhui in service of their loved ones and all of those people who reside or who stayed in the area over the lockdown period. The collective memory of Ngāti Manawa meant that they knew the Rāhui they placed in Murupara would work, however the correct protocols had to be enacted for the Rāhui to be placed.

\section{Recommendations}

This research informs the $\mathrm{MoH}$ and local authorities of the need to engage with kaumatua and see them as a valuable resource for the mobilisation of local community resources in a time where they, as governing bodies, cannot provide them adequately or quickly for vulnerable populations. The Rāhui placed in Murupara, March 23, 2020, is a legitimate and very accessible concept that is deeply rooted in $\mathrm{Te}$ Ao Māori (Ngāti Manawa) knowledge and highlights its validity going forward. This links to the simplicity of its concept that is 
widely understood and accepted by Māori and supports Rāhui as a viable policy that can be made lawful as part of the country's national response to the inevitability of future pandemics.

\section{Accepted 12 November 2021}

\section{Published 23 December 2021}

\section{References}

Boyle, C. (2020). Police say they do not encourage community checkpoints. New Zealand Herald. https://www.nzherald.co.nz/nz/covid-19coronavirus-police-say-they-do-not-encouragecommunity-checkpoints-outline-the-rules/ DLG3W5DXCTRZBSA7CZ3QMC3JKM/

Braun, V., \& Clarke, V. (2006). Using thematic analysis in psychology. Qualitative Research in Psychology, 3(2), 77-101.

Cave, D., \& Solomon, S. (2020). New Zealand beat the virus. Can they do it again? The New York Times. nytimes. com/2020/08/13/world/asia/new-zealand-coronaviruslockdown-elimination.html

Dong, E., Du, H., \& Gardner, L. (2020). An interactive web-based dashboard to track COVID-19 in real time. The Lancet Infectious Diseases, 20, 533-534.

Duncan, G. (2020). New Zealand's coronavirus elimination strategy has united a nation. Can that unity outlast lockdown? The Conversation. https://www.washingtonpost.com/world/asia_pacific/ new-zealand-isnt-just-flattening-the-curve-itssquashing-it/2020/04/07/6cab3a4a-7822-11ea-a311adb1344719a9_story.html

Earley, M. (2020, August 23). Coronavirus: Karakia rings out every day at Auckland-Waikato Covid-19 border. Stuff NZ. https://www.stuff.co.nz/national/health/ coronavirus/300088633/coronavirus-karakia-rings-outevery-day-at-aucklandwaikato-covid19-border

Fifield, A. (2020). New Zealand isn't just flattening the curve. It's squashing it. The Washington Post. https://www.washingtonpost.com/world/asia_pacific/ new-zealand-isnt-just-flattening-the-curve-itssquashing-it/2020/04/07/6cab3a4a-7822-11ea-a311adb1344719a9_story.html

Hurihanganui T (2020). Thousands find comfort in live-streamed karakia. Radio New Zealand. https://www.rnz.co.nz/news/te-manu-korihi/412507/ thousands-find-comfort-in-live-streamed-karakia

Johnsen, M. (2020a, April 21). Government's Māori Covid-19 response all words, no action- Response group. Radio New Zealand. https://www.rnz.co.nz/news/te-manukorihi/414667/government-s-Māori -covid-19-responseall-words-no-action-response-group

Johnsen, M. (2020b, May 13). Covid-19: Remote communities in Far North want checkpoints to remain in level 2. [Radio broadcast]. Radio New Zealand. https://www.rnz.co.nz/news/te-manu-korihi/416492/ covid-19-remote-communities-in-far-north-wantcheckpoints-to-remain-in-level-2
Maxwell, K., \& Penetito, W. (2007). How the use of rāhui for protection of taonga has evolved over time. MAl Review, 2(1), 1-15.

McCormack, F. (2011). Rāhui: A blunting of teeth. The Journal of the Polynesian Society, 120(1), 43.

McMeeking, S., \& Savage, C. (2020). Māori responses to COVID-19. Policy Quarterly, 16(3), 36-41.

Mead, H. M. (2003). Tikanga Māori: Living by Māori values: Huia Publishing

Ministry of Health (2020). Update COVID-19 Maori Response Action Plan. Ministry of Health.

New Zealand Government. (2020). COVID-19 alert system. Unite Against COVID-19. http://civd19.govt.nz/alertsystem/covid-19-alert-system/

Otago University. (2020). Te Ao Māori: Māori ki te whare wananga o Otakou. https://www.otago.ac.nz/Māori/ world/

Parahi, C. (2020). Coronavirus: How Māori are helping Māori handle the pain of the Covid-19 pandemic. Stuff. https://www.stuff.co.nz/national/health/ coronavirus/121049269/coronavirus-how-mori-arehelping-mori-handle-the-pain-of-the-covid19-pandemic

Peters, M. (2020, March 24). Checkpoints on coast. Gisborne Herald. http://www.gisborneherald.co.nz/localnews/20200324/protecting-the-most-vulnerable/

Scanlon, G. (2020). Relationships and the lockdown. Your Covid-19 questions answered. [Radio broadcast]. Radio New Zealand. https://www.rnz.co.nz/news/ covid-19/413407/relationships-and-the-lockdown-yourcovid-19-questions-answered

Statistics NZ. (2018). 2018 Quick stats about population counts for Murupara (2018 Census). https://www.stats. govt.nz/tools/2018-census-place-summaries/murupara.

Summers, J. A., Baker, M. G., Wilson, N., \& Baker, M. (2018). New Zealand's experience of the 1918-19 influenza pandemic: A systematic review after 100 years. New Zealand Medical Journal, 131(1487), 54-69.

Waititi, R. (2020). Māori party Rawiri Waititi on today's politics [Television broadcast]. Māori Television. https://www.facebook.com/watch/?v=330936977941303.

Whaanga, H., \& Wehi, P. (2017). Rāhui and conservation? Māori voices in the nineteenth century niupepa Māori. Journal of the Royal Society of New Zealand, 47(1), 100-106.

Wilson, S. (2020). Three reasons why Jacinda Ardern's coronavirus response has been a masterclass in crisis leadership. The Conversation. https://theconversation. com/three-reasons-why-jacinda-arderns-coronavirusresponse-has-been-a-masterclass-in-crisisleadership-135541

World Health Organisation. (2020). Pandemic responses. https://www.who.int/ihr/eocexercise/en/ 